溶接に伴う Tendon Force の支配因子と定量化に関する研究 （固有ひずみの概念を用いた溶接構造物の高度エ作精度管理システムの開発）

\author{
岡野 成威 ${ }^{* 1}$ ，望月 正人 ${ }^{* 1}$
}

\title{
Dominant factors and quantification of Tendon Force in welded structural materials (Development of accuracy management system for high quality construction in welded structures on the basis of advanced theory of inherent strain)
}

\author{
Shigetaka OKANO*1 and Masahito MOCHIZUKI ${ }^{* 1}$ \\ ${ }^{* 1}$ Osaka Univ. Dept. of Materials and Manufacturing Science \\ 2-1 Yamada-oka, Suita-shi, Osaka 565-0871, Japan
}

Received 18 May 2015

\begin{abstract}
Tendon Force is an integral value of inherent stress associated with inherent strain, which is the root cause of welding-induced longitudinal residual stress, shrinkage and bending distortion. Also, Tendon Force concept is a very useful tool for estimating the weld longitudinal shrinkage and bending distortion in large welded structures based on the elastic finite element solution. Several predictive formulae for Tendon Force have already been proposed on the basis of welding conditions, but a unified understanding of the effect of welding conditions on Tendon Force has not yet been achieved. In this paper, dominant factors influencing Tendon Force in welded structural materials were discussed through the use of theoretical and numerical approach to quantify the effect of welding conditions, such as weld heat input, material properties and dimensions of weld joint, on Tendon Force due to welding. First, numerical investigations on the effect of welding conditions on Tendon Force were systematically performed using FE-analysis. After that, the numerical results obtained were arranged according to thermal elastic-plastic parameter, which was derived from the theory of thermo-mechanical process in welding. Based on the results, it was clarified that a unified evaluation of the effect of welding conditions on Tendon Force could be achieved by means of the thermal elastic-plastic parameter. The usefulness of thermal elastic-plastic parameter was thus verified as the dominant factor influencing Tendon Force due to welding.
\end{abstract}

Key words : Tendon Force, Inherent strain, Weld heat input, Material properties, Dimensions of weld joint, Thermal elastic-plastic parameter

\section{1. 緒言}

機械・構造物の強度は溶接部で決まることが多く，溶接部の強度を支配する溶接特有の因子とその影響を十分 に理解した設計・施工が重要となる．局所的に材料の融点以上あるいはそれに近い高温に加熱される溶接部は， 溶接欠陷や形状的不連続による応力集中に加えて，破壊駆動力を増大させる残留応力・変形，破壊勒性值を低下 させる脆化などの材質劣化，熱影響部の軟化・硬化や溶接金属と母材の強度的不均質，といった母材部とは異な る特異な性質を有する。疲労・応力腐食割れなどの経年損傷やそれを起点とした低応力脆性破壊に対してはこれ らの影響がより顕著になることが知られている. そのため, 溶接に伴って生じる残留応力・変形を高精度に予測・ 評価し適切な対策を講じることは重要な技術課題の一つである.

本報で取り上げる Tendon Force（White, et al., 1980）の概念は，溶接線方向の残留応力や縦収縮・縦曲り変形 を生じさせる原因となる “固有ひずみ”と関連した外力（松岡，1983）として重要なものであり，溶接諸条件か ら固有ひずみあるいは Tendon Force を求めることができれば，固有ひずみの概念を用いた弾性解析（藤本, 1970）

No.15-00277 [DOI:10.1299/transjsme.15-00277], J-STAGE Advance Publication date : 16 September, 2015

*1 正員，大阪大学大学院工学研究科（干 565-0871 大阪府吹田市山田丘 2-1）

E-mail of corresponding author: okano@mapse.eng.osaka-u.ac.jp 
によって複雑形状を有する大型構造物における溶接変形・残留応力をより簡便に予測・評価することが可能にな る（望月他, 1996, 村川他, 1996, 野本他, 1997, 野本, 寺崎, 2000). そのため, 溶接諸条件に基づいた Tendon Force の予測式がこれまでに種々提案されているが，必ずしも統一的な見解が得られていないのが現状である. 溶接線方向固有ひずみの発生特性は，溶接中の熱忘力・ひずみ挙動を簡易的に取り扱った両端固定棒のアナロジ 一(佐藤, 大西, 1969) に基本的に従うことが知られており, 両端固定棒のアナロジーに基づいて導出された熱弾 塑性パラメータ（佐藤, 寺崎, 1976）は Tendon Force を統一的に取り扱うための指標としても有用となることが 期待されるが，そのような試みはこれまでになされていない．本報で取り上げる Tendon Force や既報（岡野，望 月，2015）で既に取り上げた角変形に対する支配因子を共に明らかにすることによって，固有ひずみの概念を用 いた弾性解析による溶接変形・残留応力の予測・評価システムの高精度化に繋がる “溶接諸条件依存性を考慮し た固有ひずみデータベースの構築”に向けた基礎的知見を得ることが可能になるといえる.

本報では，Tendon Forceに及ぼす溶接諸条件の影響について数值シミュレーションを活用した系統的な検討を 行い，溶接入熱・材料特性・試験体寸法の各因子の影響を定量的に評価した上で，それらの影響を体系的に理解 し，統一的に定量化するための指標としての熱弾塑性パラメータの有用性について検証する.

\section{2. 溶接に伴うTendon Force の支配因子と定量化に関する既往研究}

\section{$2 \cdot 1$ 両端固定棒のアナロジーによる溶接線方向の固有ひずみの発生特性に関する従来知見}

Tendon Force の生成原因は溶接線方向のみを完全拘束して得られる固有応力源であり, 固有応力は固有ひずみ を与えた物体を固有ひずみを与える前の形状に維持するのに必要な応力であるから，溶接によって生じる溶接線 方向の固有ひずみが Tendon Force の生成原因といえる. したがって, 溶接に伴う Tendon Force の支配因子を明ら かにする上で，溶接線方向の固有ひずみの発生特性を基礎としたアプローチが有用であると考えられる.

溶接線方向の固有ひずみの発生特性は, 図 1 に示寸両端固定棒のアナロジーに基本的に従うことが知られてい る.ここでは簡単のため, 材料の降伏応力 $\sigma_{\mathrm{Y}}$ とヤング率 $E$ の温度依存性を同じ形で表し, 線膨張係数 $\alpha$ を温度 によらず一定としているが，溶接線方向の固有ひずみの発生特性を理解する上で実際的にそれほど大きな問題を 生じない. また，材料（棒）の初期温度は $0^{\circ} \mathrm{C}$ とて議論を進めることとする. 両端を固定された棒では見かけ のひずみは完全拘束されるため, 温度上昇に伴う熱ひずみ $\varepsilon_{\mathrm{t}}(=\alpha T)$ は弾性ひずみ $\varepsilon_{\mathrm{e}}$ もくは塑性ひずみ $\varepsilon_{\mathrm{p}}$ とし て受け持たれる，温度上昇が小さい範囲では材料（棒）は弾性状態にあり塑性ひずみを生じないが，或る温度 $T_{\mathrm{p}}$ $\left(=\varepsilon_{\mathrm{Y}} / \alpha\right)$ に達すると熱ひずみは弾性ひずみだけでは受け持てなくなり, 材料（棒）は圧縮降伏し塑性ひずみを生 じる. そして，それ以降の温度上昇に伴う熱ひずみは全て塑性ひずみとして受け持たれることになる，一方，そ の後の泠却過程では, 加熱時の温度上昇量に応じて材料挙動が異なる. 最高到達温度 $T_{\max }$ が $2 T_{\mathrm{p}}$ より小さいと, 温度低下に伴う熱ひずみは全て弾性ひずみとして受け持たれるため新たな塑性ひずみを生じない.すなわち，温 度上昇過程で生じた塑性ひずみが冷却後もそのまま残留する. 最高到達温度 $T_{\max }$ が $2 T_{\mathrm{p}}$ より大きいと, 冷却過程 初期の温度低下による熱ひずみは弾性ひずみとして受け持たれるものの, 温度が $T_{\max }-2 T_{\mathrm{p}}$ まで低下した際に材料

（棒）は引張降伏し，その後の温度低下による熱ひずみは塑性ひずみとして受け持たれることになる. その結果， 完全冷却後には降伏ひずみ $\varepsilon_{Y}$ に等しい大きさの圧縮塑性ひずみが残留する，以上の両端固定棒のアナロジーによ る溶接線方向の固有ひずみの発生特性を縓めると, 最高到達温度に応じて次の式(1), (2), (3)のように表される.

$$
\begin{aligned}
& \varepsilon_{\mathrm{p}}=0 \quad\left(T_{\max }<T_{\mathrm{p}}\right) \\
& \varepsilon_{\mathrm{p}}=-\alpha T_{\max }+\varepsilon_{\mathrm{Y}} \quad\left(T_{\mathrm{p}} \leq T_{\max }<2 T_{\mathrm{p}}\right) \\
& \varepsilon_{\mathrm{p}}=-\varepsilon_{\mathrm{Y}} \quad\left(2 T_{\mathrm{p}} \leq T_{\max }\right)
\end{aligned}
$$

溶接部における最高到達温度の分布が既知であれば，溶接に伴う固有ひずみの分布は図 2 に示すように求めら れる. 最高到達温度 $T_{\max }$ に線膨張係数 $\alpha$ を乗じた熱ひずみ $\alpha T_{\max }$ のうち, 加熱過程における最高到達温度が力学 
的溶融温度 $T_{\mathrm{m}}$ を超えない範囲ではこれから降伏ひずみ $\varepsilon_{\mathrm{Y}}$ 差し引いた大きさの圧縮塑性ひずみ一 $\left(\alpha T_{\max }-\varepsilon_{\mathrm{Y}}\right)$ が生 じ，力学的溶融温度を超えた範囲では熱ひずみと等しい大きさの圧縮塑性ひずみ一 $\alpha T_{\max }$ が生じると考える．完全 冷却後には，最高到達温度が $2 T_{\mathrm{p}}$ を超えた範囲では，結局のところ降伏ひずみ $\varepsilon_{\mathrm{Y}}$ に等しい大きさの圧縮塑性ひず み- $\varepsilon_{Y}$ が残留することになり，溶接線方向の固有ひずみは，図中に示す台形のような分布を呈する．本簡易モデ ルによる溶接線方向の固有ひずみの発生特性については実験的にもその有用性が確かめられている（寺崎他, 2000).
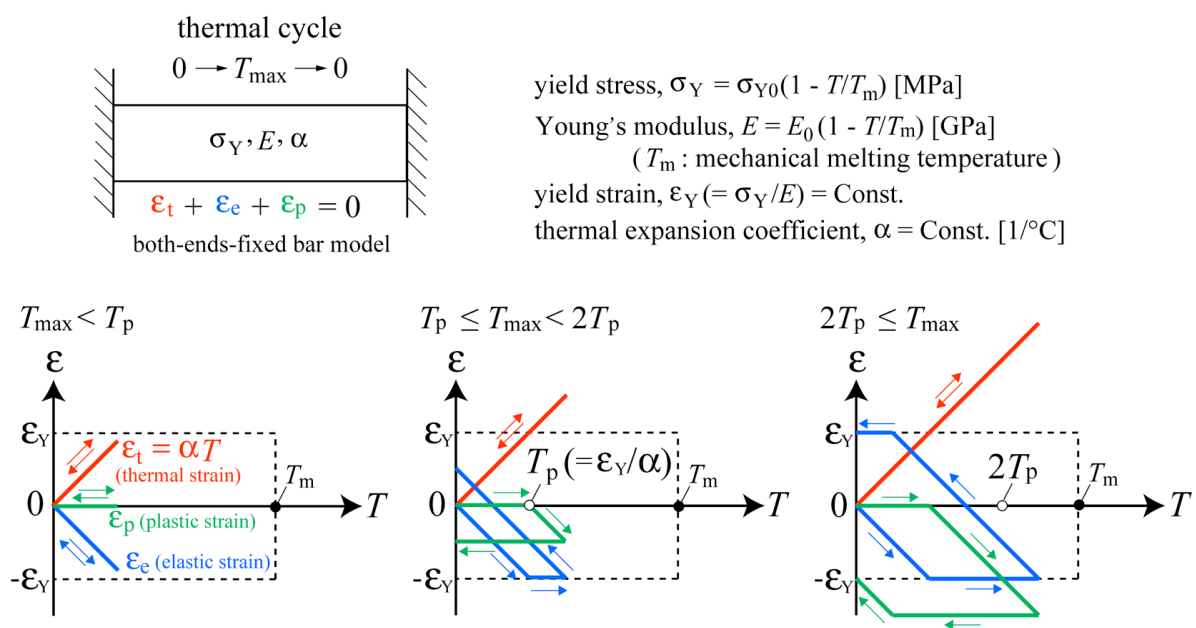

Fig. 1 Schematic illustration of generation characteristics of thermal, elastic and plastic strains on the basis of both-ends-fixed bar analogy. Values of inherent strain (plastic strain) were divided into three categories according to highest temperature rise.

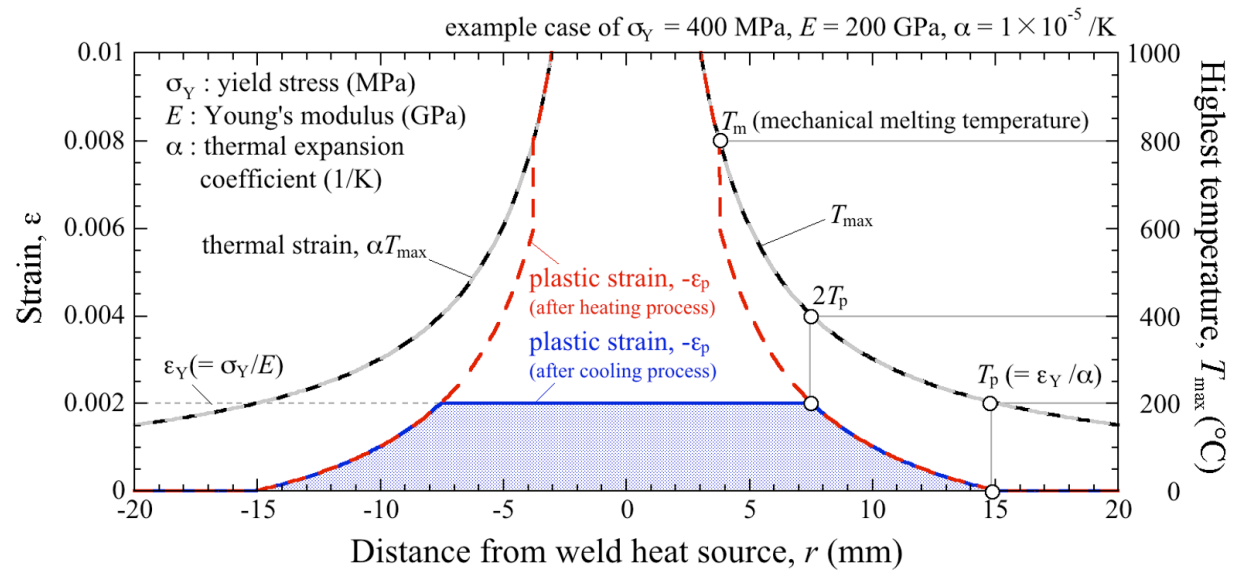

Fig. 2 Schematic illustration of distribution characteristics of inherent strain due to welding. Welding thermal stress and strain behavior results in the trapezoidal distribution of inherent strain on the basis of both-ends-fixed bar analogy.

\section{$2 \cdot 2$ 溶接に伴う Tendon Force の定量化に関する従来知見}

Tendon Force は，図 2 に示した溶接線方向の固有ひずみの分布を板厚断面（面積を $A$ とする）全体で積分し， これにヤング率 $E$ を乗じた式(4)によって求めることができる.

$$
F_{\mathrm{T}}=-E \int \varepsilon_{\mathrm{p}} d A
$$


ただし， $F_{\mathrm{T}}$ : Tendon Force, $\varepsilon_{\mathrm{p}}$ : 溶接線方向の固有ひずみ, である. 両端固定棒のアナロジーによれば固有ひずみ は最高到達温度に依存して決まるため, 溶接熱伝導論に基づいて溶接諸条件から最高到達温度の分布を求めれば Tendon Force も求めることが可能になる．このような手順で溶接諸条件から Tendon Force を定量的に予測する取 り組みがこれまでになされている. Sasayama, et al.（1955）は，板幅とスティフナ高さが十分に大きな T 断面桁の 多パス寸み肉溶接によって生じる Tendon Force を求める式(5)を提案している.

$$
F_{\mathrm{T}}=0.181 E \alpha Q_{\text {net }} / c \rho
$$

ただし, $Q_{\text {net }}$ : 単位溶接長当りの溶接入熱, $c$ : 比熱, $\rho$ : 密度, であり, ここでは溶接入熱として多パス溶接時の 総入熱量を用いている. White（1977）は，鋼の平板に溶接した際の Tendon Force の実測結果と 2 次元有限差分 法による解析結果に基づいて Tendon Force を求める式(6)を提案している.

$$
F_{\mathrm{T}}=200 Q_{\text {net }}
$$

成田他（1997）, 羅他（1999）は，溶接による最高到達温度分布が瞬間平面熱源で取り扱える場合について，両 端固定棒のアナロジーによる固有ひずみの発生特性に基づいて, 平板の Tendon Force を求める式(7)を提案してい る他, 有限要素法による熱弾塑性解析結果から式(8)を提案している.

$$
\begin{aligned}
& F_{\mathrm{T}}=0.335 E \alpha Q_{\text {net }} / c \rho \\
& F_{\mathrm{T}}=160 Q_{\text {net }}
\end{aligned}
$$

寺崎他（2000）は，両端固定棒のアナロジーに基づいた固有ひずみ分布を台形近似し，溶接による最高到達温 度分布が瞬間平面熱源もしくは瞬間線熱源で取り扱える場合の Tendon Force を求める式(9), (10)をそれぞれ提案 している．また，固有ひずみ分布を台形近似せず，溶接による最高到達温度分布が瞬間平面熱源で取り扱える場 合には Tendon Force は上述の式(7)によって求まることを示し，これを用いれば平板の縦収縮（寺崎他，2002）や $\mathrm{T}$ 型すみ肉継手の縦曲り変形（寺崎他，2003）を精度良く評価できることを示している．なお，同様に固有ひず み分布を台形近似せず，溶接による最高到達温度分布が瞬間線熱源で取り扱える場合には Tendon Force は式(11) によって求めることができる，ここで，式(7)と式(9), あるいは, 式(10)と式(11)をそれぞれ比較して見ると, 固 有ひずみ分布を台形近似した際には Tendon Force を 1 割弱程度大きく見積もることがわかる.

$$
\begin{aligned}
& F_{\mathrm{T}}=0.363 E \alpha Q_{\text {net }} / c \rho \\
& F_{\mathrm{T}}=0.268 E \alpha Q_{\text {net }} / c \rho \\
& F_{\mathrm{T}}=0.253 E \alpha Q_{\text {net }} / c \rho
\end{aligned}
$$

以上に示したように，両端固定棒のアナロジーによる固有ひずみの発生特性に基づく Tendon Force の予測式は 種々に提案されているが，これらに共通の特徴として，Tendon Force は溶接入熱に対して比例関係にあり，その 
比例定数 $k$ は溶接熱源の形態に依存する他，ヤング率や線膨張係数が大きいほど，あるいは，熱容量（比熱滵 度）が小さいほど大きく，また，材料の降伏応力には影響されないといえる。ここで，鋼を想定して，ヤング率 $E$ を $200 \mathrm{GPa}$, 線膨張係数 $\alpha$ を $1.2 \times 10^{-5} /{ }^{\circ} \mathrm{C}$, 比熱 $c$ を $500 \mathrm{~J} / \mathrm{kg}^{\circ} \mathrm{C}$, 密度 $\rho$ を $8.0 \times 10^{-5} \mathrm{~kg} / \mathrm{mm}^{3}$ として Tendon Force, $F_{\mathrm{T}}$ $[\mathrm{N}]$ と溶接入熱 $Q_{\mathrm{net}}[\mathrm{J} / \mathrm{mm}]$ の関係を表す比例係数 $k$ を求めて比較した結果を表 1 に示す． Sasayama, et al.の結果は 溶接熱源を瞬間平面熱源あるいは瞬間線熱源としたどちらの場合とも明らかに異なっているが，これは多パス溶 接時の Tendon Force を総入熱量で評価した際には, 各パスでの固有ひずみ発生領域が重なり合い, 見かけ上の比 例係数 $k$ が小さく見積もられることに起因していると考えられる. White の実験結果（式(6)）や村川らの熱弾塑 性解析結果（式(8)）はいずれもアーク溶接を対象としたものであるにも関わらず，前者が瞬間平面熱源の場合と 良く一致しているのに対して, 後者は瞬間線熱源の場合と比較的良く一致しており, この違いの原因は必ずしも 明らかでない，一般に，アーク溶接では溶接熱源を瞬間線熱源として取り扱う場合が多いが，板厚が比較的小さ い場合などでは温度分布が板厚貫通型に近くなり, 注目する温度域によっては瞬間平面熱源として取り扱える場 合もある. 以上から分かるように, 従来の Tendon Force の予測式には継手板厚等の寸法に関する因子が考慮され ておらず，溶接諸条件から Tendon Force をより精度良く見積もるためには，継手寸法の影響を考慮し，さらには その適用範囲を明らかにしておくことが実用上極めて重要であるといえる.

Table 1 Comparison of estimated proportionality coefficients between Tendon Force and weld heat input.

\begin{tabular}{ccc}
\hline Theoretically-derived prediction formula & Proportionality coefficient, $k\left(=F_{\mathrm{T}} / Q_{\text {net }}\right)$ & Remarks \\
\hline$F_{\mathrm{T}}=0.181 E \alpha Q_{\text {net }} / c \rho$ & 108.6 & T-joint, multi-pass \\
$F_{\mathrm{T}}=0.335 E \alpha Q_{\text {net }} / c \rho$ & 201.0 & instantaneous plane heat source \\
$F_{\mathrm{T}}=0.253 E \alpha Q_{\text {net }} / c \rho$ & 151.8 & instantaneous line heat source \\
\hline
\end{tabular}

\section{Tendon Forceに及ぼす溶接諸条件の影響とその統一的評価}

\section{$3 \cdot 1$ Tendon Force に及ほす溶接諸条件の影響の検討}

本節では，Tendon Forceに及ぼす溶接諸条件の影響について有限要素法による熱弾塑性解析を活用して系統的 な検討を行う，対象とする材料は，構造用鋼，高強度鋼（構造用鋼に対して降伏応力のみを 2 倍にしたもの）, オ ーステナイト系ステンレス鋼，アルミニウム合金を想定した計 4 種類とし，それぞれの材料について図 3 に示寸 温度依存性を考慮して表 2 に示す材料特性を用いた。

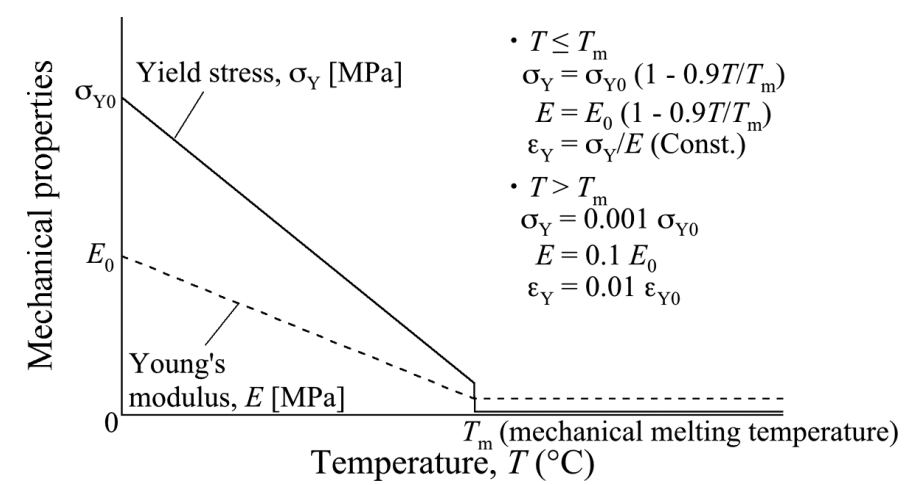

Fig. 3 Temperature dependencies of yield stress and Young's modulus used. Same temperature dependencies are considered in yield stress and Young's modulus. As the result, yield strain is constant with temperature under mechanical melting temperature. 
Okano and Mochizuki, Transactions of the JSME (in Japanese), Vol.81, No.830 (2015)

Table 2 Material properties used for four different kinds of materials.

\begin{tabular}{|c|c|c|c|c|}
\hline & $\begin{array}{l}\text { Structural steel } \\
\text { (Lower strength) }\end{array}$ & $\begin{array}{l}\text { Structural steel } \\
\text { (Higher strength) }\end{array}$ & $\begin{array}{c}\text { Austenitic } \\
\text { stainless steel }\end{array}$ & Aluminum alloy \\
\hline Specific heat, $c\left[\mathrm{~J} / \mathrm{kg}^{\circ} \mathrm{C}\right]$ & 500 & 500 & 500 & 800 \\
\hline Density, $\rho\left[\mathrm{kg} / \mathrm{mm}^{3}\right]$ & $8.0 \times 10^{-6}$ & $8.0 \times 10^{-6}$ & $8.0 \times 10^{-6}$ & $2.7 \times 10^{-6}$ \\
\hline Thermal conductivity, $\lambda\left[\mathrm{W} / \mathrm{mm}^{\circ} \mathrm{C}\right]$ & $5.2 \times 10^{-2}$ & $5.2 \times 10^{-2}$ & $1.4 \times 10^{-2}$ & $1.6 \times 10^{-1}$ \\
\hline Young's modulus at initial temperature, $E_{0}[\mathrm{GPa}]$ & 200 & 200 & 200 & 75 \\
\hline Poisson's ratio, $v$ & 0.33 & 0.33 & 0.33 & 0.33 \\
\hline Yield stress at initial temperature, $\sigma_{\mathrm{Y} 0}[\mathrm{MPa}]$ & 400 & 800 & 280 & 150 \\
\hline Yield strain at initial temperature, $\varepsilon_{Y 0}$ & $2.0 \times 10^{-3}$ & $4.0 \times 10^{-3}$ & $1.4 \times 10^{-3}$ & $2.0 \times 10^{-3}$ \\
\hline Thermal expansion coefficient, $\alpha[1 / \mathrm{K}]$ & $1.2 \times 10^{-5}$ & $1.2 \times 10^{-5}$ & $1.8 \times 10^{-5}$ & $2.4 \times 10^{-5}$ \\
\hline Yielding temperature, $T_{\mathrm{p}}\left(=\varepsilon_{\mathrm{Y}} / \alpha\right)\left[{ }^{\circ} \mathrm{C}\right]$ & 167 & 333 & 78 & 83 \\
\hline Mechanical melting temperature, $T_{\mathrm{m}}\left[{ }^{\circ} \mathrm{C}\right]$ & 800 & 800 & 1100 & 440 \\
\hline Melting temperature, $T_{\text {melt }}\left[{ }^{\circ} \mathrm{C}\right]$ & 1500 & 1500 & 1500 & 640 \\
\hline
\end{tabular}

まず，継手板厚の影響について検討を行う，板厚のみの影響を検討する上で，板長や板幅による剛性変化の影 響が含まれないことが望ましい，そのためには板長や板幅が十分に大きなモデルを用いればよいが，本検討では 計算コスト削減の観点から数值解析モデルとして，図 4 に示寸試験体の中央における板厚断面を想定して平面ひ ずみ状態としたモデルを用いた．溶接部における要素分割は最小で $0.5 \mathrm{~mm} \times 0.5 \mathrm{~mm} \times 1.0 \mathrm{~mm}$ としている. 初期温度 を $0^{\circ} \mathrm{C}$ とし, 最高到達温度が $T_{\mathrm{p}}$ に達する領域に対して板幅端部の熱反射による影響が生じないように十分に広い 板幅とした. 検討条件は, 表 3 に示寸ように, 板厚を $10,20,30 \mathrm{~mm}$ の 3 種類, 単位溶接長当りの溶接入熱を $100 \mathrm{~J} / \mathrm{mm}$ から $1200 \mathrm{~J} / \mathrm{mm}$ まで $100 \mathrm{~J} / \mathrm{mm}$ 毎に変化させた 12 種類とし，これらを組合せた計 36 条件である. 各条件において 熱弾塑性解析によって得られた溶接線方向の固有ひずみの分布から式(4)を用いて Tendon Force を算出した.

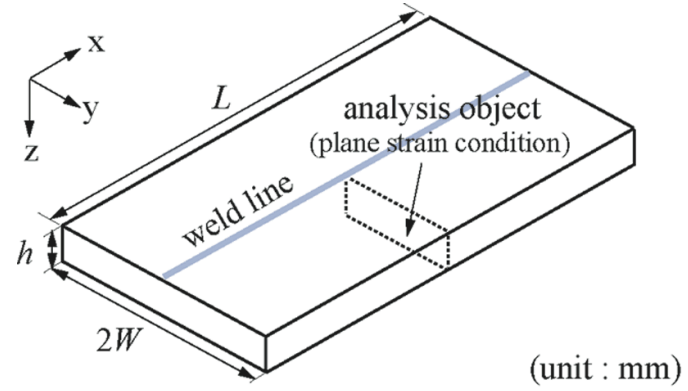

Fig. 4 Analysis object in this examination. The simplified model of plane strain condition corresponding thickness section at center of welded plate was considered.

Table 3 Welding conditions.

\begin{tabular}{cc}
\hline Plate thickness, $h(\mathrm{~mm})$ & Weld heat input, $Q_{\text {net }}(\mathrm{J} / \mathrm{mm})$ \\
\hline $10,20,30$ & $100,200,300,400,500,600,700,800,900,1000,1100,1200$ \\
\hline
\end{tabular}


まず初めに，構造用鋼の場合を取り上げて，溶接入熱と Tendon Force の関係に及ぼす継手板厚・大気中への熱 放散の有無の影響をそれぞれ評価した，その結果を図 5 に示す，なお，ここでは大気中への熱放散として熱伝達 (熱伝達率 $15 \times 10^{-6} \mathrm{~W} / \mathrm{mm}^{2 \circ} \mathrm{C}$ ) とステファン・ボルツマン則に従う熱放射を考慮している. 図より, Tendon Force と溶接入熱の関係は継手板厚によって明らかに影響されているといえる。溶接入熱が同じであれば板厚が小さい 方が Tendon Force が大きい傾向にあるが，その程度は溶接入熱の大きさによっても異なっており，溶接入熱と継 手板厚の両因子が複雑に影響し合っていることが示唆される結果となっている，一方，大気中への熱放散の影響 については，板厚が小さい，もしくは，溶接入熱が大きいほどより顕著に見られるが，継手板厚の影響と比較し て見るとそれほど大きくないといえる. すなわち, 溶接諸条件に基づいた Tendon Force の予測式の高精度化に向 けては, 断熱状態を想定した溶接熱伝導論に基づいたアプローチにはそれほど大きな問題は無く, 継手寸法の影 響を考慮に入れることの方がむしろ重要であると考えられる.

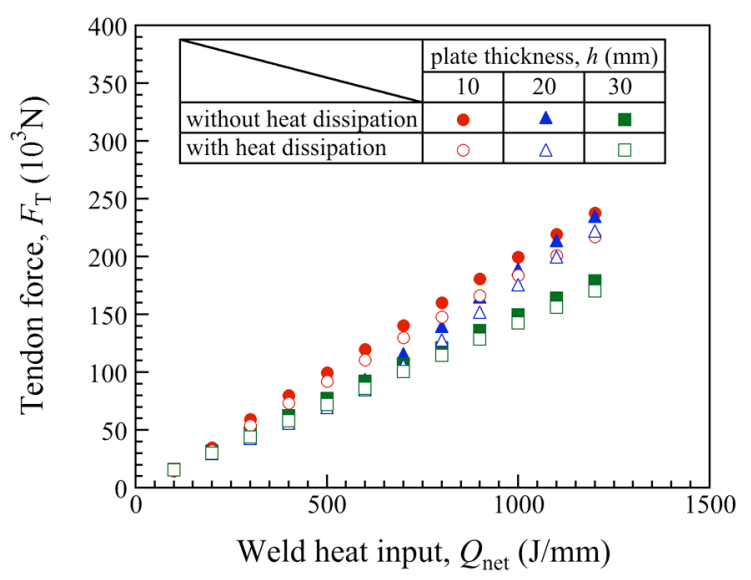

Fig. 5 Effects of plate thickness and heat dissipation on relation between weld heat input and Tendon Force in structural steel (lower strength). The relation is obviously influenced by plate thickness rather than heat dissipation.

そこで，大気中への熱放散を考慮しない場合を取り上げて，溶接入熱と Tendon Force の関係に及ぼす継手板厚 の影響を材料毎に評価した．それらの結果を図 6(a)から図 6(d)に示寸，それぞれの図には，各材料において溶接 熱源を瞬間平面熱源あるいは瞬間線熱源として取り扱った際の両端固定棒のアナロジーに基づく Tendon Force の 理論值を併せて示している. なお，これらの Tendon Force の理論值は，表 2 に示す各材料における物性值を用い て式(7)および式(11)によりそれぞれ求めた。 これらの図より，いずれの材料においても，Tendon Force の熱弾塑 性解析結果（図中プロット）は溶接熱源を瞬間平面熱源とした場合の理論值（図中破線）を上限，溶接熱源を瞬 間線熱源とした場合の理論值（図中実線）を下限とした範囲内にあることがわかる。しかしながら，その範囲内 における変化傾向は材料に応じて大きく異なっており, 例えば, 構造用鋼と比較して, オーステナイト系ステン レス鋼やアルミニウム合金の場合には, 板厚 $30 \mathrm{~mm}$ における小入熱条件を除いたほぼ全ての条件で, Tendon Force は溶接熱源を瞬間平面熱源とした場合の理論値と良く一致する傾向が見られる. また，板厚 $20 \mathrm{~mm}$ の場合を見る と, 構造用鋼では溶接入熱が大きくなるに従って Tendon Force は溶接熱源を瞬間線熱源とした場合の理論值から 溶接熱源を瞬間平面熱源とした場合の理論值へと変化していく傾向を示しているが，高強度鋼では全ての溶接入 熱において溶接熱源を瞬間線熱源とした場合の理論值と良く一致している。これは, 前章で示した Tendon Force の予測式に関する従来知見において, Tendon Force は降伏応力に影響されないとされたことと矛盾しており, Tendon Force の支配因子に関するより詳細な検討の必要性を示唆するものであるといえる. 


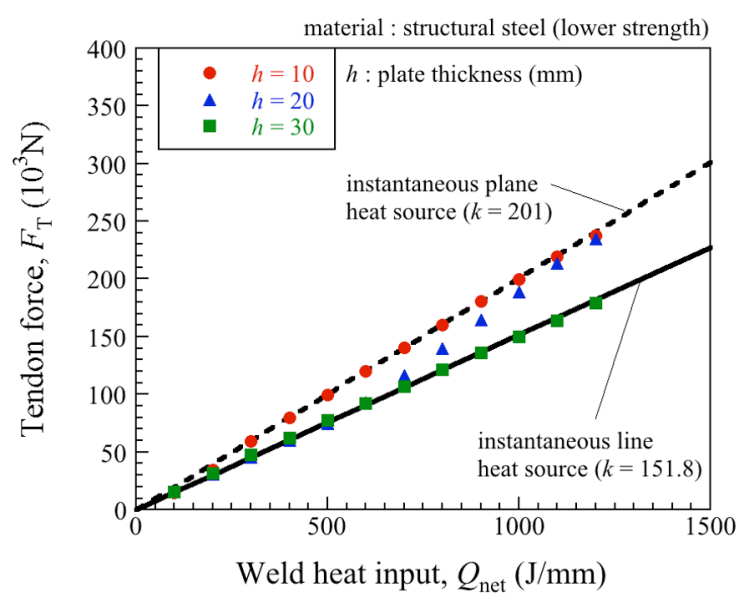

(a) Structural steel (lower strength)

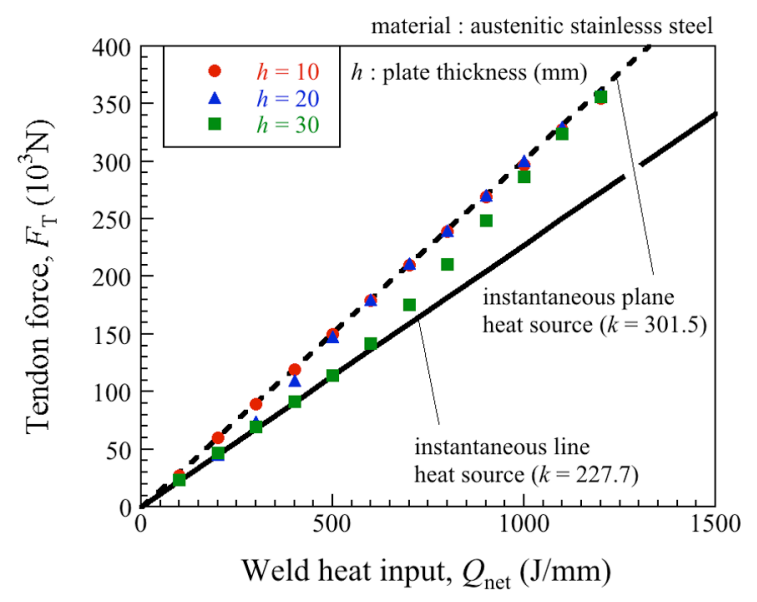

(c) Austenitic stainless steel

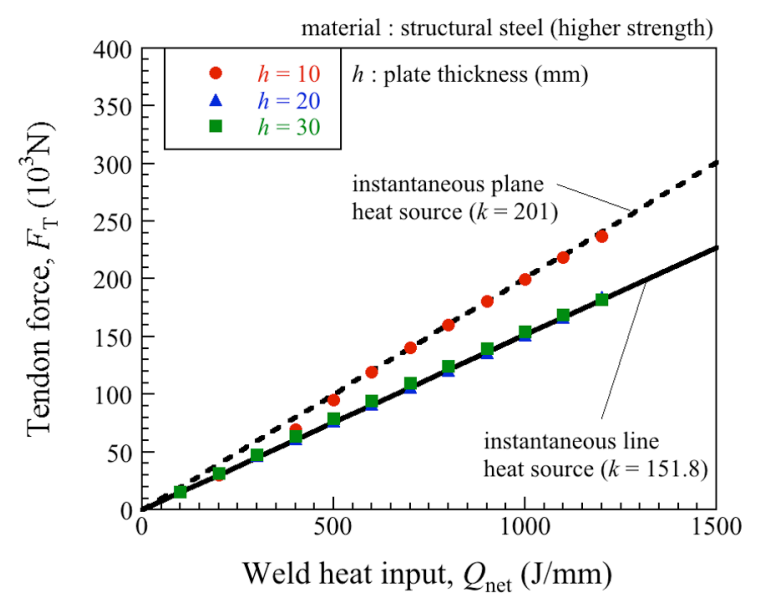

(b) Structural steel (higher strength)

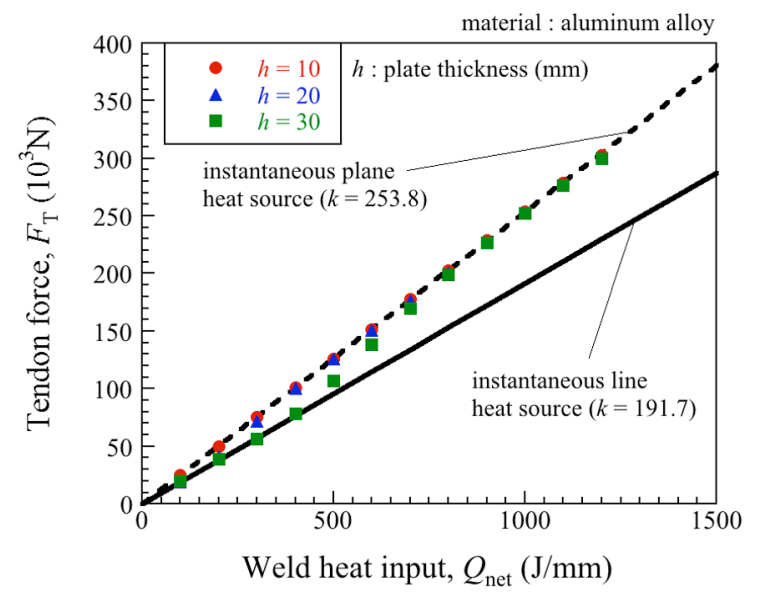

(d) Aluminum alloy

Fig. 6 Differences in the effect of plate thickness on relation between weld heat input and Tendon Force according to material properties. The effect of plate thickness on relation between weld heat input and Tendon Force is obviously influenced by material properties.

続いて，継手板幅の影響について検討を行う。本検討では，数值解析モデルとして図 4 に示すような平板の 3 次元モデルを用いた. 板長 (図 4 中の $L$ ) を端部効果が生じない程度に十分大きな寸法として $1500 \mathrm{~mm}$ で固定し, 板幅 $2 W$ （片幅を $W$ とする）を表 4 に示すように種々に変化させた。一般に，継手板幅の影響が懸念されるのは 板厚に対して溶接入熱が比較的大きな場合が想定されるため，本検討では板厚 $10 \mathrm{~mm}$ の場合を対象とし，板厚断 面における溶接線方向の固有ひずみの発生領域に対応する温度分布が溶接熱源を瞬間平面熱源とした場合で取り 扱える条件として溶接入熱 600 および $1200 \mathrm{~J} / \mathrm{mm}$ の 2 条件を取り上げた. いずれも，上述の 4 種類全ての材料に 対して同様に検討を行い, Tendon Force は溶接線方向中央断面において先と同様の手順で式(4)によって算出した.

Table 4 Welding conditions.

\begin{tabular}{cc}
\hline Weld heat input, $Q_{\text {net }}(\mathrm{J} / \mathrm{mm})$ & Plate width, $2 W(\mathrm{~mm})$ \\
\hline 600,1200 & $200,300,450,600,900,1200,1500$ \\
\hline
\end{tabular}


Tendon Force に及ぼす継手板幅の影響を評価した結果を図 7 に示す．縦軸には，溶接熱源を瞬間平面熱源とし た場合の理論值（板幅を無限大と見なした場合の比例係数 $k_{\mathrm{W}=\infty}$ ）で無次元化した比例係数 $k / k_{\mathrm{W}=\infty}$ 用いている. 図より，継手板幅が大きいと Tendon Force は溶接熱源を瞬間平面熱源とした場合の理論值とおよそ等しい（k/ $k_{\mathrm{W}=\infty}=1 ）$ が，継手板幅が小さくなるにつれて溶接熱源を瞬間平面熱源とした場合の理論值よりも小さくなつてい く傾向にある。また，その程度は鋼ではほとんど見られないほど小さいのに対して，オーステナイト系ステンレ ス鋼やアルミニウム合金ではより顕著である。また，溶接入熱によってもその程度は異なっており，Tendon Force に及ぼす継手板幅の影響は材料特性や溶接入熱によって複雑に異なることが示唆される.

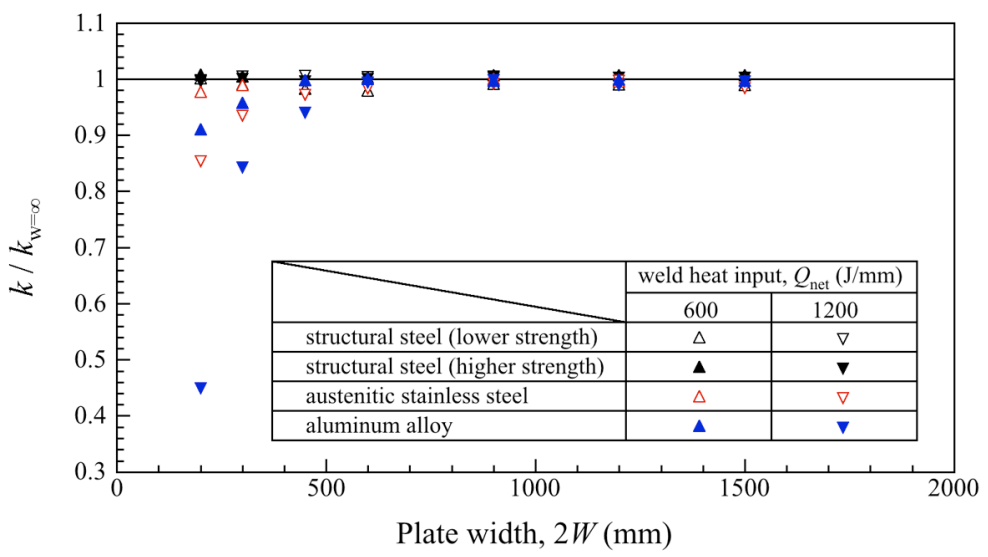

Fig. 7 Effects of material properties and weld heat input on relation between plate width and Tendon Force due to welding. Tendon force is the same with the estimated value on the basis of both-ends-fixed bar analogy in case that plate width is large enough. On the other hand, Tendon Force decreases differently depending on material properties and weld heat input with decrease in plate width.

\section{$3 \cdot 2$ Tendon Force に及ぼす溶接諸条件の影響の統一的評価}

前節までの検討から，溶接入熱と材料特性に基づいた従来の Tendon Force の理論的予測は，継手板厚や継手板 幅によって明らかに影響を受けており，溶接諸条件からのより高精度な Tendon Force の予測にはこれらの因子の 影響を考慮できる指標が必要であるといえる。Tendon Force に及ぼす継手板厚・板幅の影響を考慮するためには, 板厚断面における固有ひずみの発生領域と板厚断面の寸法の関係に注目する必要があると考えられ，溶接線方向 固有ひずみの発生領域に対応すると考えられる最高到達温度が $T_{\mathrm{p}}$ に達する領域が板厚断面内においてどの程度 拡がっているのかを考慮した指標が求められる，そのような指標として，佐藤，寺崎（1976）は板厚方向のそれ に対しては熱弾塑性パラメータ $\alpha Q_{\mathrm{net}} / c \rho \varepsilon_{\mathrm{Y}} h^{2}$ を, 板幅方向のそれに対しては熱弾塑性パラメータ $\alpha Q_{\mathrm{net}} / 2 c \rho h \varepsilon_{\mathrm{Y}} W$ を それぞれ提案している。

そこで, Tendon Forceに対する継手板厚・継手板幅の影響について，これらのパラメータをそれぞれ用いて図 6 および図 7 に示した結果の再整理を行った。それらの結果を図 8 および図 9 に示す. 縦軸には Tendon Force あ るいは Tendon Force と溶接入熱の関係を表す比例定数をそれぞれ用いているが，どちらも溶接熱源を瞬間平面熱 源とした場合の理論值で無次元化したものとしている．いずれの図を見ても，Tendon Forceの傾向はそれぞれの 熱弾塑性パラメータに対して統一した 1 本の曲線でおよそ評価できており, Tendon Force を統一的に定量化する ための指標としてこれらの熱弾塑性パラメータが極めて有用となり得ることがわかる. 


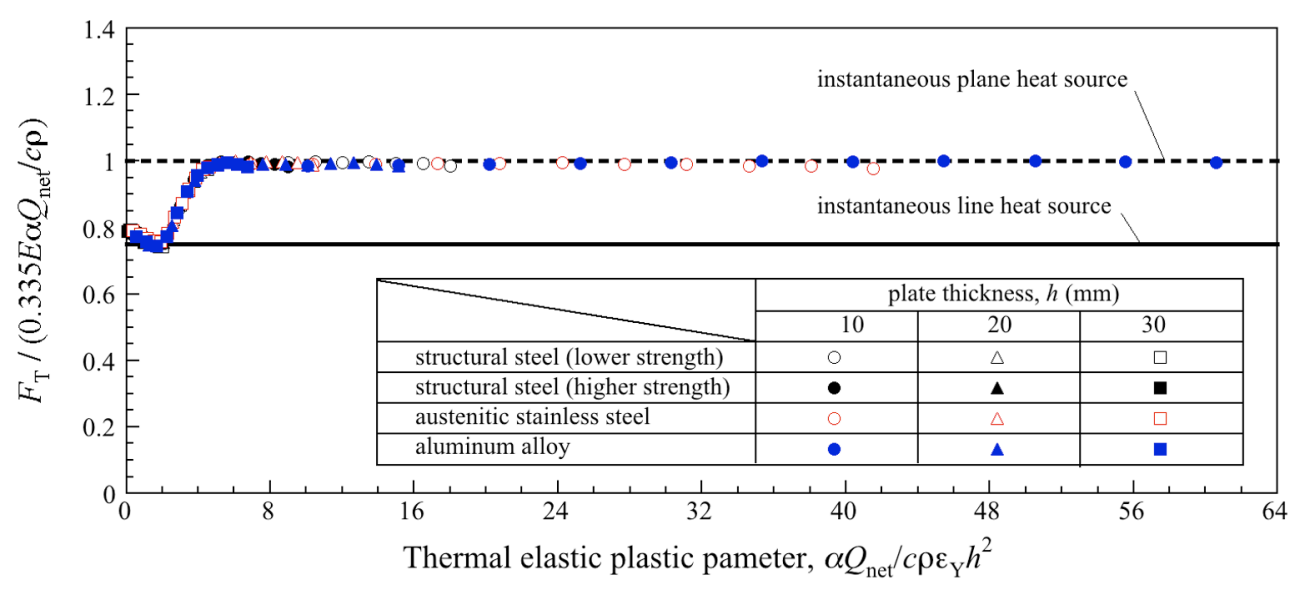

Fig. 8 Quantification of the effect of plate thickness on relation between welding conditions and Tendon Force due to welding by means of thermal elastic plastic parameter, $\alpha Q_{\text {net }} / c \rho \varepsilon_{\mathrm{Y}} h^{2}$. The effect of plate thickness on relation between welding conditions and Tendon Force produced in various structural materials can be arranged coordinately by means of thermal elastic-plastic parameter, $\alpha Q_{\text {net }} / c \rho \varepsilon_{\mathrm{Y}} h^{2}$.

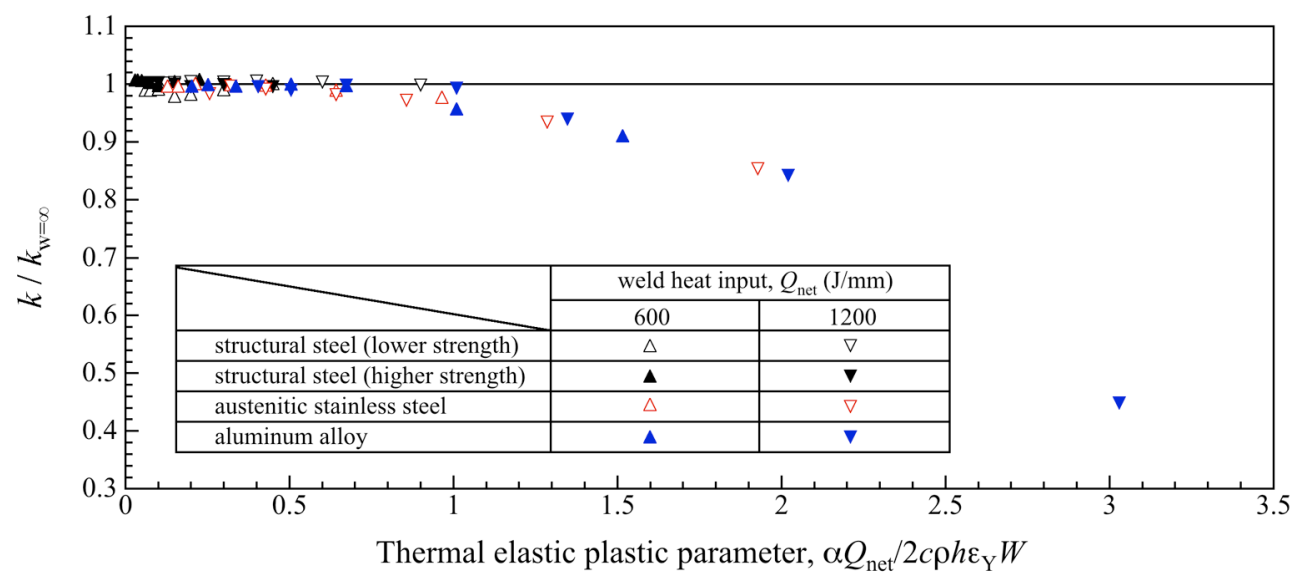

Fig. 9 Quantification of the effect of plate width on relation between welding conditions and Tendon Force due to welding by means of thermal elastic plastic parameter, $\alpha Q_{\text {net }} / 2 c \rho h \varepsilon_{Y} W$. The effect of plate width on relation between welding conditions and Tendon Force produced in various structural materials can be arranged coordinately by thermal elastic-plastic parameter, $\alpha Q_{\text {net }} / 2 c \rho h \varepsilon_{\mathrm{Y}} W$.

また, 図 8 より, 熱弾塑性パラメータ $\alpha Q_{\mathrm{net}} / c \rho \varepsilon_{Y} h^{2}$ が小さい条件範囲で Tendon Force は溶接熱源を瞬間線熱源 とした場合の理論值と良く一致し，熱弾塑性パラメータ $\alpha Q_{\mathrm{net}} / c \rho \varepsilon_{\mathrm{Y}} h^{2}$ が大きい条件範囲で Tendon Force は溶接熱 源を瞬間平面熱源とした場合の理論值と良く一致することが見てとれる. なお, 熱弾塑性パラメータ $\alpha Q_{\mathrm{net}} / c \rho \varepsilon_{\mathrm{Y}} h^{2}$ が 2 程度よりも小さい条件範囲において熱弾塑性パラメータ $\alpha Q_{\text {net }} / c \rho \varepsilon_{\mathrm{Y}} h^{2}$ が小さくなるにつれて比例係数 $k$ 僅か ながら上昇する傾向が見られるが，これは有限要素法における離散化に伴う誤差に因るものであり本質的なもの ではない. 板厚断面において溶接線方向の固有ひずみの発生領域に対応すると考えられる最高到達温度が $T_{\mathrm{p}} に$ 達 する領域の深さが板厚の半分より小さければ，その領域寸法は板裏面での熱反射の影響を受けず溶接熱源を瞬間 線熱源として取り扱った場合と等しくなるため, Tendon Force は溶接熱源を瞬間線熱源とした理論值と一致する と考えられる.この最高到達温度が $T_{\mathrm{p}}$ に達する領域の深さが板厚の半分になるときの熱弾塑性パラメータ 
$\alpha Q_{\text {net }} / c \rho \varepsilon_{\mathrm{Y}} h^{2}$ を溶接熱伝導論に基づいて求めると 1 程度であり, 図 8 に示寸熱弾塑性解析結果の傾向とも比較的良 い対応が見られる．また，熱弾塑性パラメータ $\alpha Q_{\text {net }} / c \rho \varepsilon_{Y} h^{2}$ が 6 程度よりも大きくなると Tendon Force は溶接熱 源を瞬間平面熱源とした場合の理論值と良く一致するといえる. 一方, 図 9 を見ると, 熱弾塑性パラメータ $\alpha Q_{\text {net }} / 2 c \rho h \varepsilon_{\mathrm{Y}} W$ が大きくなるにつれて Tendon Force は溶接熱源を瞬間平面熱源とした場合の理論值よりも減少し ていく傾向を示すが, 熱弾塑性パラメータ $\alpha Q_{\text {net }} / 2 c \rho h \varepsilon_{\mathrm{Y}} W$ が 0.5 程度までは Tendon Force は溶接熱源を瞬間平面熱

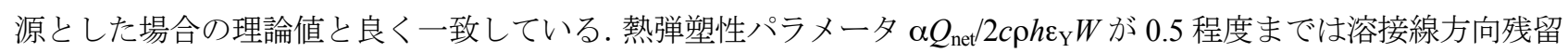
応力の板幅方向分布が継手板幅に影響されず溶接入熱条件のみに依存する（佐藤，寺崎，1976）ことから，これ は溶接線方向の固有ひずみの発生特性が継手板幅の影響をほとんど受けないためであると考えられる.

以上のように, 溶接に伴う Tendon Force に対する溶接諸条件の影響に関して, 継手板厚・板幅の影響をも含め た統一的な評価指標として, 熱弾塑性パラメータ $\alpha Q_{\text {net }} / c \rho \varepsilon_{Y} h^{2}$ と $\alpha Q_{\text {net }} / 2 c \rho h \varepsilon_{\mathrm{Y}} W$ がそれぞれ有用であることを明ら かにした，本指標を用いれば，両端固定棒のアナロジーによる固有ひずみの発生特性に基づいた Tendon Force の 理論的予測式の適用範囲や想定すべき溶接熱源の形態を適切に判断でき, 溶接諸条件に基づいたより高精度な Tendon Force の定量化が可能になるといえる. 実際の構造物の製作で多く用いられる多層・多パスの溶接への適 用に向けては，既存溶接パスまでに生じている固有ひずみの発生領域との干渉効果や残留応力分布による影響を 更に考慮に入れる必要があるが，本報で示した溶接諸条件（熱弾塑性パラメータ $\alpha Q_{\mathrm{net}} / c \rho \varepsilon_{\mathrm{Y}} h^{2} や \alpha Q_{\mathrm{net}} / 2 c \rho h \varepsilon_{\mathrm{Y}} W$ ) に基づいた Tendon Forceの定量化方法は既存溶接パスまでに生じている固有ひずみの発生領域やそれに伴って生 じる残留応力分布を見積もる上でも有用となると考えられる．これらの取り組みを通して，固有ひずみの概念を 用いた複雑形状を有する大型構造物の溶接変形・残留応力予測・評価システムの高精度化に繋がることが期待さ れる.

\section{4. 結}

\section{言}

本報では，溶接に伴う Tendon Forceに及ぼす溶接諸条件の影響に関する体系的な理解のために数值シミュレー ションを活用した系統的な検討を行うとともに, Tendon Force の統一的な定量化のための指標として両端固定棒 のアナロジーによる固有ひずみの発生特性に基づいた熱弾塑性パラメータの有用性について考察を加えた. 以下 に得られた結論を示す.

（1）数值シミュレーションを活用した系統的な検討によって，Tendon Forceに及ぼす溶接入熱，材料特性，継 手板厚・板幅の影響を定量的に評価した結果, Tendon Force は溶接入熱に対して単調増加する関係にあり, 継手板厚や熱容量（比熱×密度）が小さい, あるいは, 線膨張係数やヤング率, 継手板幅が大きいほど, 同じ溶接入熱であっても Tendon Force は大きくなることを示した.

（2）溶接入熱・材料特性と Tendon Force の関係に及ぼす継手板厚の影響は，板厚断面における溶接線方向の 固有ひずみの発生領域の深さを継手板厚で無次元化した熱弾塑性パラメータ $\alpha Q_{\mathrm{net}} / c \rho \varepsilon_{\mathrm{Y}} h^{2}$ によって統一的 に評価できる．熱弾塑性パラメータ $\alpha Q_{\mathrm{net}} / c \rho \varepsilon_{\mathrm{Y}} h^{2}$ が 1 程度よりも小さい条件範囲では溶接熱源を瞬間線熱 源とした場合, 熱弾塑性パラメータ $\alpha Q_{\mathrm{net}} / c \rho \varepsilon_{\mathrm{Y}} h^{2}$ が 6 程度よりも大きい条件範囲では溶接熱源を瞬間平面 熱源とした場合，の両端固定棒のアナロジーによる固有ひずみの発生特性に基づく Tendon Force の理論 的予測式が適用可能である.

（3）溶接入熱・材料特性と Tendon Force の関係に及ぼす継手板幅の影響は，板厚断面における溶接線方向の 固有ひずみの発生領域の幅を継手板幅で無次元化した熱弾塑性パラメータ $\alpha Q_{\mathrm{net}} / 2 c \rho h \varepsilon_{\mathrm{Y}} W$ にって統一的 に評価できる. 熱弾塑性パラメータ $\alpha Q_{\mathrm{net}} 2 c \rho h \varepsilon_{\mathrm{Y}} W$ が 0.5 程度よりも小さい条件範囲では溶接熱源を瞬間 平面熱源とした場合の両端固定棒のアナロジーによる固有ひずみの発生特性に基づく Tendon Force の理 論的予測式が適用可能である.

\section{文献}

藤本二男, 固有ひずみの概念による溶接残留応力および溶接変形の解析法 - 溶接残留応力および溶接変形の解析 
（第 1 報）-，溶接学会誌，Vol. 39, No. 4 (1970), pp. 236-252.

羅宇, 石山隆庸, 村川英一, 縦曲りを有する板における溶接変形に関する研究, 溶接構造シンポジウム 1999 講演 概要集 (1999), pp. 290-296.

松岡一祥，溶接製殼構造物の残留応力に関する一解法，日本造船学会論文集，No. 153 (1983), pp. 210-217.

望月正人，林眞琴，中川正紀，多田信雄，清水禎人，厚板を貫通する配管溶接部における残留応力の簡易弾性解 析法の検討，日本機械学会論文集 A 編，Vol. 62, No. 597 (1996),pp. 1250-1255.

村川英一，羅宇，上田幸雄，固有ひずみを用いた弾性計算による溶接変形および残留応力の推定一（第 1 報）溶 接における固有ひずみの生成機構 -, 日本造船学会論文集, No. 180 (1996), pp. 739-751.

成田健一, 樺澤真事, 村川英一, 固有ひずみを用いた薄肉閉断面部材の溶接変形予測, 溶接構造シンポジウム 1997 講演概要集 (1997), pp. 290-296.

野本敏治, 武市祥司, 青山和浩, 溶接変形の予測に基づく精度管理システムに関する研究, 日本造船学会論文集, No. 181 (1997), pp. 249-260.

野本敏治, 寺崎俊夫, 固有ひずみを媒介としたパイプ円周溶接で生じる残留応力と溶接変形の予測, 日本機械学 会論文集 A 編, Vol. 66, No. 642 (2000),pp. 374-381.

岡野成威，望月正人，固有ひずみの発生特性に基づく溶接角変形支配因子に関する研究（固有ひずみの概念を用 いた溶接構造物の高度工作精度管理システムの開発)，日本機械学会論文集，Vol. 81, No. 826 (2015) DOI: 10.1299/transjsme.15-00118.

Sasayama, T., Masubuchi, K. and Moriguchi, S., Longitudinal deformation of long beam due to fillet welding, Welding Journal, Vol. 34, No. 12 (1955), pp. 581s-582s.

佐藤邦彦, 大西毅, 両端固定棒のアナロジーによる溶接熱影響部の過渡的熱応力の研究, 溶接学会誌, Vol. 38, No. 4 (1969), pp. 359-371.

佐藤邦彦，寺崎俊夫，構造用材料の溶接残留応力・溶接変形に及ぼす溶接諸条件の影響, 溶接学会誌, Vol. 45, No. 1 (1976), pp. 42-50.

寺崎俊夫, 中谷光良, 石村知樹, 溶接継手に生ずる Tendon Force について, 溶接学会論文集, Vol. 18, No. 3 (2000), pp. 479-486.

寺崎俊夫, 石村知樹, 松石研一, 秋山哲也, ビードオンプレート溶接継手に生じる縦収縮に関する研究, 溶接学 会論文集，Vol. 20, No. 1 (2002), pp. 136-142.

寺崎俊夫, 北村貴典, 城戸田嚴, 石村知樹, 浜島志伸, 寸み肉 $\mathrm{T}$ 継手に生じる縦収縮・縦曲り変形に関する研究, 溶接学会論文集, Vol. 21, No. 1 (2003), pp. 81-86.

White, J. D., Longitudinal shrinkage of a single pass weld, CUED/C-StRUCT/TR. 57 (1977).

White, J. D., Leggatt, R. H. and Deight, J. B., Weld shrinkage prediction, Welding and Metal Fabrication, November (1980), pp. 567-596.

\section{References}

Fujimoto, T., A method for analysis of residual welding stresses and deformations based on the inherent strain - a theoretical study of residual welding stresses and deformations (report 1) -, Journal of the Japan Welding Society, Vol. 39, No. 4 (1970), pp. 236-252 (in Japanese).

Luo, Y., Ishiyama, M. and Murakawa, H., Study on welding deformation of plate with longitudinal curvature, Proceedings of Symposium on Welding Structure (1999), pp. 290-296 (in Japanese).

Matsuoka, K., An analytical method on residual stresses in welded built-up shell structures, Journal of the Society of Naval Architects of Japan, No. 153 (1983), pp. 210-217 (in Japanese).

Mochizuki, M., Hayashi, M., Nakagawa, M., Tada, N. and Shimizu, S., Residual stress estimation at welded joint of a pipe penetrating a thick plate, Transactions of the Japan Society of Mechanical Engineers Series A, Vol. 62, No. 597 (1996), pp. 1250-1255 (in Japanese).

Murakawa, H., Luo, Y. and Ueda, Y., Prediction of welding deformation and residual stress by elastic FEM based on inherent strain - (first report) mechanism of inherent strain -, Journal of the Society of Naval Architects of Japan, No. 180 (1996), pp. 739-751 (in Japanese).

Narita, K., Kabasawa, S. and Murakawa, H., Prediction of welding deformation of thin walled closed section members using inherent strain, Proceedings of Symposium on Welding Structure (1997), pp. 290-296 (in Japanese).

Nomoto, T., Takechi, S. and Aoyama, K., Basic studies on accuracy management system based on estimating of welding 
deformations, Journal of the Society of Naval Architects of Japan, No. 181 (1997), pp. 249-260 (in Japanese).

Nomoto, T. and Terasaki, T., Prediction of residual stress and welding deformation generated by pipe welding through the medium of inherent strain, Transactions of the Japan Society of Mechanical Engineers Series A, Vol. 66, No. 642 (2000), pp. 374-381 (in Japanese).

Okano, S. and Mochizuki, M., Dominant factors influencing weld angular distortion from a viewpoint of generation characteristics of inherent strain (Development of accuracy management system for high quality construction in welded structures on the basis of advanced theory of inherent strain), Transactions of the JSME (in Japanese), Vol. 81, No. 826 (2015) DOI: 10.1299/transjsme.15-00118.

Sasayama, T., Masubuchi, K. and Moriguchi, S., Longitudinal deformation of long beam due to fillet welding, Welding Journal, Vol. 34, No. 12 (1955), pp. 581s-582s.

Satoh, K. and Ohnishi, T., Transient thermal stresses of weld heat-affected zone by both-ends-fixed bar analogy, Journal of the Japan Welding Society, Vol. 38, No. 4 (1969), pp. 359-371 (in Japanese).

Satoh, K. and Terasaki, T., Effect of welding conditions on residual stresses distributions and welding deformation in welded structures materials, Journal of the Japan Welding Society, Vol. 45, No. 1 (1976), pp. 42-50 (in Japanese).

Terasaki, T., Nakatani, M. and Ishimura, T., Study of tendon force generating in welded joint, Quarterly Journal of the Japan Welding Society, Vol. 18, No. 3 (2000), pp. 479-486 (in Japanese).

Terasaki, T., Ishimura, T., Matsuishi, K. and Akiyama, T., Study of longitudinal shrinkage of bead-on-plate, Quarterly Journal of the Japan Welding Society, Vol. 20, No. 1 (2002), pp. 136-142 (in Japanese).

Terasaki, T., Kitamura, T., Kidota, I., Ishimura, T. and Hamashima, S., Study on longitudinal shrinkage and bending distortion of fillet T joint, Quarterly Journal of the Japan Welding Society, Vol. 21, No. 1 (2003), pp. 81-86 (in Japanese).

White, J. D., Longitudinal shrinkage of a single pass weld, CUED/C-StRUCT/TR. 57 (1977).

White, J. D., Leggatt, R. H. and Deight, J. B., Weld shrinkage prediction, Welding and Metal Fabrication, November (1980), pp. 567-596. 